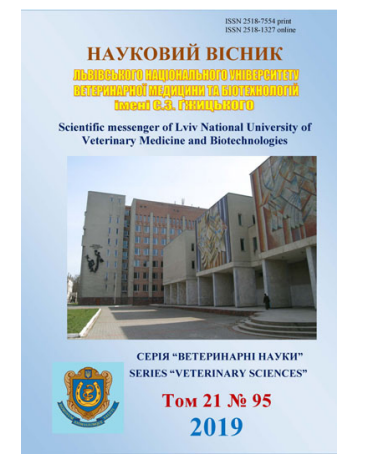

Науковий вісник Дьвівського націонадьного університету ветеринарної медицини та біотехнологій імені С.3. Гжицького. Серія: Ветеринарні науки

Scientific Messenger of Lviv National University of Veterinary Medicine and Biotechnologies. Series: Veterinary sciences

UDC 636.09: 614.4: 636.4:579.882

\title{
Chlamydiales order bacteria in swine with reproductive disoders. Detection of Waddlia chondrophila in swine
}

\author{
V.K. Zezekalo \\ Poltava State Agrarian Academy, Poltava, Ukraine
}

Article info

Received 20.09.2019

Received in revised form 21.10.2019

Accepted 22.10.2019

Poltava State Agrarian Academy, Skovorody Str., 1/3, Poltava, 36003, Ukraine.

Tel.: +38-095-645-56-26

E-mail:v.zezekalo@gmail.com

Zezekalo, V.K. (2019). Chlamydiales order bacteria in swine with reproductive disoders. Detection of Waddlia chondrophila in swine. Scientific Messenger of Lviv National University of Veterinary Medicine and Biotechnologies. Series: Veterinary sciences, 21(95), 122-126. doi: $10.32718 /$ nvlvet 9523

Chlamydial infections cause significant economic expenses due to infertility, insufficient productivity growth, and high mortality rates among young stock. Bacteria of the Chlamydiaceae family (Chlamydia suis Chlamydia abortus, Chlamydia psittaci and Chlamydia pecorum) are well known pathogens isolated from pigs. The diseases associated with these species are widely studied; monitoring and prevention are carried out. However, chlamydia-related bacteria in swine remain poorly studied in Ukraine. The purpose of the study was to check samples, taken from swine from private farms in the Poltava region, Ukraine, for the presence of Chlamydia-like organisms. Determination of the possibility of coinfection of Chlamydia and Chlamydia-like organisms. We examined 28 samples from two private farms in the Poltava region (23 samples from sows, and 5 samples from boars). The studies were carried out using PCR with primers designed in our laboratory. As a result of the study, Chlamydiaceae-positive samples were not detected among sows. Along with it, 2 out of 5 samples taken from boars were found to be Chlamydiaceae-positive. The total number of Chlamydiaceae-positive samples was 2 out of 28 (7.14\%). The total number of Waddlia-positive samples was 8 out of 28 (28.7\%). A mixture of Chlamydiaceae and Waddlia chondrophila infection was found in one sample. Parachlamydia acanthamoebae was not found in any sample. There are no reports of the detection of Waddlia chondrophila in samples from swine in the sources available for us, so this publication might be the first such report. Due to the fact that $W$. chondrophila was first detected in the samples selected from pigs, the experiment was repeated three times, and the identity of the PCR product of W. chondrophila-positive samples was additionally verified by restriction analysis. Relatively small number of samples, in our research as well as in previous studies, does not allow us to make accurate calculations about the prevalence of chlamydia-like organisms in swine. Further research are required and might include broader sampling, isolation of the pathogen, sequencing of its genome, experimental infection, determination of pathomorphological changes. All the listed above, would help to determine significance of the study along with the role of $W$. chondrophila in chlamydia infection in swine.

Key words: Chlamydia-like organisms, Chlamydiaceae, Parachlamydia acanthamoebae, pigs, PCR, Ukraine.

\section{Бактерії порядку Chlamydiales у зразках від свиней 3 репродуктивними розладами. Виявлення Waddlia chondrophila у свиней}

\author{
В.К. Зезекало
}

Полтавська державна аграрна академія, м. Полтава, Украӥна

Хламідійні інфекиії є причиною значних економічних втрат, зумовлених непліддям, недоотриманням приплоду, зниженням продуктивності, високою смертністю молодняка. Бактерії родини Chlamydiaceae (Chlamydia suis Chlamydia abortus, Chlamydia psittaci та Chlamydia pесотит), щзо найчастіше виділяють від свиней, иироко вивчаються, проводиться моніторинг та профілак- 
тика захворювань. Проте хламідіє-споріднені бактерії у свиней залишаються мало вивченими. Метою иього дослідження було з 'ясувати стан щуодо хламідійної інфекиї в умовах одноосібних селянських та фермерських господарств Полтавської області, а також спростувати чи підтвердити наявність хламідіє-подібних організмів у зразках, відібраних від свиней, та можливість конфекиіï Chlamydiaceaе та хламідіє-подібних організмів. 3 иією метою було досліджено 28 зразків з двох одноосібних фермерських господарств Полтавської області. Дослідження проводилися методом ПЛР з використанням праймерів власного дизайну. В результаті дослідження Chlamydiaceaе-позитивних зразків серед відібраних у свиноматок виявлено не було, проте 2 з 5 зразків, взятих у кабанів, виявилися Chlaтуdiaceае-позитивними. Загальна кількість Сһlaтудіасеае-позитивних серед відібраних проб становила 2 з 28 (7,14\%). Загальна кількість Waddlia- позитивних зразків становила 8 з 28 (28,7\%). P. асапthатоеbае не виявлено у жодному зразку. В одному зразку виявлено конфекиію Chlamydiaceae ma W. Chondrophila. B зв'язку з тим, щзо W. chondrophila y зразках, відібраних від свиней, нами була виявлена вперше, дослід було повторено триразово, а ідентичність ПЛР-продукту W. chondrophila-позитивних проб додатково було перевірено рестрикиійним аналізом. Порівняно невелика кількість зразків як у намому дослідженні, так і в попередніх дослідженнях не дозволяє нам зробити точні розрахунки щьоо поширеності хламідієподібних організмів у свиней. Потрібні подальші дослідження, які повинні включати ширшу вибірку, виділення збудника, секвенування його геному з подальшим його аналізом, проведення експериментальних заражень тварин з визначенням патоморфологічних змін. Все перераховане вище допоможе визначити значущість даної знахідки та визначити роль W. chondrophila для свинарства.

Ключові слова: хламідієподібні організми, Chlamydiaceae, Parachlamydia acanthamoеbае, ПЛР, Україна.

\section{Вступ}

Хламідійні інфекції виявляють у широкого кола як свійських, так і диких тварин, вони є причиною захворювань, що призводять до значних економічних втрат у тваринництві, крім того, ендемічні для тварин хламідійні види становлять потенційну загрозу для здоров'я людини (Burnard \& Polkinghorne, 2016). Незважаючи на численні дослідження, діагностика хламідіозів залишається нелегкою справою через відсутність типової клінічної картини, розповсюдження хламідійних видів серед нехарактерних господарів та частих випадків міжвидової передачі (Burnard \& Polkinghorne, 2016; Taylor-Brown \& Polkinghorne, 2017; Borel et al., 2018). Досі немає ефективних вакцин, які могли б використовуватися для профілактики хламідіозів, а для контролю хламідійних інфекцій як у тварин, так і в людей використовуються антибіотики, застосування котрих не завжди призводить до бажаного результату (Kohlhoff \& Hammerschlag, 2015; Kong et al., 2015). Найбільше занепокоєння в зв'язку широким використанням антибіотиків викликає поява антибіотикорезистентності серед хламідійних видів. Chlamydia suis наразі є єдиним відомим видом хламідій, що містить генну касету резистентності до тетрациклінів, яка в лабораторних умовах може бути передана від C. suis, інших хламідійних видів шляхом рекомбінації (Longbottom, 2004; Suchland et al., 2009; Schautteet \& Vanrompay, 2011; Joseph et al., 2016). Хламідійні інфекції у свиней пов'язують з репродуктивними розладами, кон'юнктивітами, ентеритами, пневмоніями, поліартритами, плевритами та перикардитами, непліддям, абортами, муміфікацією плода, слабким і нежиттєздатним потомством, зниженням якості сперми, орхітами та уретритами у кабанів. Захворювання репродуктивної системи, непліддя, аборти спричиняють значні економічні втрати у свинарстві. Етіологічний фактор вищезгаданих захворювань вдається виявити не завжди.

Свині - природний господар C. suis, проте цей вид хламідій також виявляють і в людини, ВРХ, коней, котів, жаб, курей та інших видів птахів (Zezekalo et al., 2019). Крім С. suis, від свиней найчастіше виділяють Chlamydia abortus, Chlamydia psittaci та Chlamydia pecorum (Schautteet \& Vanrompay, 2011).
Щодо ролі хламідіє-споріднених бактерій у розвитку репродуктивних розладів у свиней, то це питання залишається маловивченим. Всі проведені раніше дослідження базуються на незначних вибірках, одні вчені заявляють про відсутність хламідіє-споріднених бактерій у свиней, інші ж говорять про незначну кількість (близько 3,5\%) сумнівно-позитивних зразків серед поросят (Koschwanez et al., 2012; Van Gils et al., 2015), Di Francesco at al. наполягають на наявності Parachlamydia у пробах від диких свиней (Sus scrofa) (Di Francesco et al., 2013).

Хламідійні інфекції, що пов'язують з бактеріями родини Chlamydiaceae, досить часто зустрічаються у свиней, вони широко вивчаються, проводиться моніторинг та профілактика захворювань. Преваленція хламідійної інфекції у племінному свинарстві в Україні на 2014 рік становила приблизно 71\% (Ksonz, 2014), в іноземних джерелах йдеться про розповсюдженість на рівні 92-94\% (Hoffmann et al., 2015). Проте хламідіє-споріднені бактерії у свиней залишаються маловивченими.

Власне хламідії та хламідіє-споднені бактерії генетично подібні та розділяють однаковий цикл розвитку. Waddlia chondrophila, Parachlamydia acanthamoebae - хламідіє-споріднені бактерії, що пов'язують з захворюваннями репродуктивної системи жуйних та людини, які є причиною абортів, народження кволого чи нежиттєздатного потомства, респіраторних захворювань (Greub, 2009; Baud et al., 2014; Stephan et al., 2014; Hornung et al., 2015). Саме тому вчені, що проводили дослідження свиней, щодо хламідіє-подібних організмів акцентували свою увагу саме на вищезазначених видах (Koschwanez et al., 2012; Van Gils et al., 2015).

До цього часу дослідження стосовно хламідієподібних організмів в Україні не проводилися. В зв'язку 3 цим актуальними $є$ дослідження свиней щодо хламідієспоріднених організмів.

Метою дослідження було 3'ясувати стан щодо хламідійної інфекції в умовах одноосібних селянських та фермерських господарств Полтавської області а також спростувати чи підтвердити наявність хламідієподібних організмів в зразках, відібраних від свиней, та можливість конфекції Chlamydiaceae та хламідієподібних організмів. 


\section{Матеріал і методи досліджень}

Дослідження проводились в умовах лабораторії здоров'я тварин та лабораторії генетики Інституту свинарства та АПВ НААН, що сертифікована для проведення генетичного аналізу на рівні ДНК (Свідоцтво про відповідність стану системи вимірювань № 021-19 від 31.01.2019p).

Упродовж зимового періоду 2018 року в двох одноосібних фермерських господарствах Полтавської області відібрано 28 зразків матеріалу для дослідження у тварин з підозрою щодо хламідійної інфекції. Відбиралися вагінальні зішкреби від свиноматок та ректальні зішкреби від кнурів. Відбір проб здійснювали у промарковані пробірки з транспортним середовищем за допомогою стерильних одноразових мультизондів. Свиней для дослідження відбирали за згодою фермерів 3 діагностичною метою. Маніпуляції $з$ тваринами проводили згідно з Європейською конвенцією "Про захист хребетних тварин, які використовуються для експериментальних і наукових цілей”, “Загальних етичних принципів експериментів на тваринах”.

Дослідження проводили методом полімеразної ланцюгової реакції (ПЛР), здійснюючи за допомогою ПЛР-тест-систем власної розробки для індикації Waddlia chondrophila, Parachlamydia acanthamoebae за геном, що кодує $16 \mathrm{~S}$ рРНК, та ПЛР-тест-системи для виявлення Chlamydiaceae spp за геном, що кодує головний білок мембрани (МОМР) (таб.1). Крім того, у нашому дослідженні використані зразки контрольних ДНК, отримані від європейських дослідників (зразки ДНК: P. acanthamoebae штами - "Berg17" та "Bn9", ДНК P. acanthamoebae штам Hall, Waddlia chondrophila, Chlamydia avium, Chlamydia pecorum, Chlamydia abortus, Chlamydia psittaci, Chlamydia suis, Chlamydia caviae, Chlamydia felis, Chlamydia muridarum, Chlamydia pneumoniae, Chlamydia gallinacea).

Виділення ДНК. До 100 мкл буферного розчину 3 досліджуваним матеріалом додавали 500 мкл “ДНКекспрес", змішували вміст пробірки на вортексі 10 секунд, після чого витримували 10 хвилин при температурі $98 \mathrm{C}^{\circ}$ та центрифугували при 13 тис. об/хв протягом 1 хв. Супернатант використовували для постановки реакції ампліфікації.

ПЛР-аналіз відібраних проб. Ампліфікацію ДНК виконували з використанням реагентів "Thermo Fisher Scientific, US”, кожна реакція проводилася в об'ємі 25 мкл, згідно 3 рекомендаціями виробника. У ПЛР використовувались олігонуклеотидні праймери: пара праймерів для ідентифікації хламідій родини (Ksonz \& Pocherniaiev, 2009) та дві пари праймерів для ідентифікації хламідіє-подібних організмів $W$. chondrophila та P. acanthamoebae (Zezekalo et al., 2018; 2019) (табл. 1).

\section{Таблиця 1}

Праймери, що використовувалися для дослідження

\begin{tabular}{lccc}
\hline \multicolumn{1}{c}{ Вид } & Ген & Праймери & Розмір продукт \\
\hline Chlamydiaceae spp & $16 \mathrm{~S}$ rRNA & $\begin{array}{l}\text { CHMOSPF: AGGTGAGTATGAAAAAACTC } \\
\text { CHMOSPR: TCGAAAACATAATCTCCGTA }\end{array}$ & 221 п.н. \\
\hline Waddlia chondrophila & $16 \mathrm{~S}$ rRNA & $\begin{array}{l}\text { WADCHOF:GAACGAAGTGTGCTCTTGAGT } \\
\text { WADCHOR:CCTCTCTAGCACCATATCCGG }\end{array}$ & 123 п.н. \\
\hline $\begin{array}{l}\text { Parachlamydia } \\
\text { acanthamoebae }\end{array}$ & $16 \mathrm{~S}$ rRNA & $\begin{array}{l}\text { PCHAF:CAAGGTAGCCCTATCGGAAG } \\
\text { PCHAR:CTTGCCCAACCTCGGAAGAT }\end{array}$ & 88 п.н. \\
\hline
\end{tabular}

На першому етапі була проведена ПЛР з першою парою праймерів для виявлення бактерій родини Chlamydiaceae. Після цього - два триразові прослідовні тести: 1 - 3 використанням праймерів для виявлення $W$. chondrophila, 2 - 3 використанням праймерів для виявлення P. acanthamoebae. Ампліфікацію ДНК за допомогою ПЛР проводили на програмованому термостаті ТЕРЦИК-2 (ДНК-Технологии, РФ). Продукти ПЛР розділяли за допомогою $2 \%$ агарозного гель-електрофорезу у $1 \times$ Трис-боратному електродному буфері (TBE) упродовж 2 год за сили струму 50 мА в електрофоретичній камері (Cleaver Scientific Ltd. UK). Як маркер молекулярної маси використовували ДНК плазміди $p U C 19$, гідролізованої ендонуклеазою $M s p$ I. Після закінчення електрофорезу гель фарбували розчином бромистого етидію $\left(10 \mathrm{Mг} / \mathrm{cm}^{3}\right)$ та фотографували за допомогою системи гельдокументації (Cleaver Scientific Ltd. UK).

\section{Результати та їх обговорення}

В результаті проведеного дослідження P. acanthamoebae не виявлена в жодному випадку, кількість $W$. chondrophila-позитивних зразків 6323 (26,09\%), відібраних від свиноматок, та 2 з 5, відібраних від кнурів. Всього 328 досліджених тварин $W$. chondrophila - позитивними виявились 8, що склало 28,7\%. Chlamydiaceae-позитивних зразків серед свиноматок не було, проте 2 зразки з 5, відібраних від кнурів, були Chlamydiaceae-позитивними. Загальна ж кількість Chlamydiaceae-позитивних зразків становила 2328 (7,14\%). Змішані інфекції бактерій родини Chlamydiaceae та W. chondrophila були виявлені в одному випадку.

До цього часу в доступних для нас джерелах інформації не було повідомлень про виділення $W$. chondrophila у свиней. Отже, W. chondrophila у свиней нами виявлена вперше, тому був додатково проведений рестриктний аналіз для визначення ідентичності продукту ПЛР, одержаного в результаті ампліфікації праймерів W. chondrophila специфічних 3 
досліджуваною ДНК та контрольною ДНК W. chondrophila. Для рестрикційного аналізу використовувалась Hin1II ендонуклеаза, згідно з протоколом виробника. В результаті рестрикції утворювались два фрагменти 53 та 70 пар нуклеотидів, що підтверджує ідентичність продукту ПЛР, одержаного в результаті ампліфікації (рис. 1).

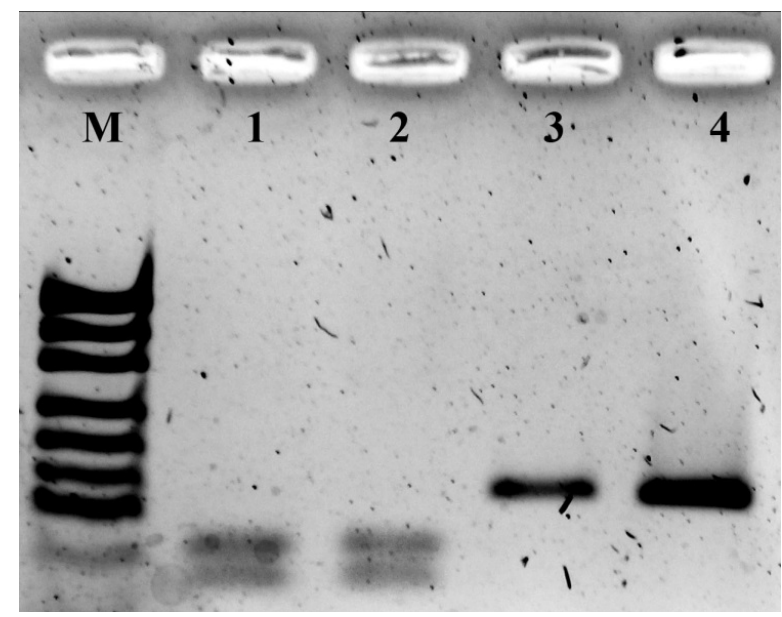

Рис. 1. Електрофареграма рестрикційного аналізу:

M - маркер молекулярної маси ДНК плазміди рUC19;

1 - рестрикиія продукту ампліфікаиіï W.chondrophila cneuифічних праймерів з досліджуваною ДНК; 2- рестрикиія продукту ампліфікаиії W.chondrophila специфічних праймерів контрольною ДНК W.chondrophila;3- продукт ампліфiкаиіï W.chondrophila специфічних праймерів з досліджуваною ДНК; 4- продукту ампліфікаиї W. chondrophila специ-

фічних праймерів контрольною ДНК W.chondrophila.

Отримані дані стосовно наявності ДНК $P$. acanthamoebae збігаються 3 такими, що проводилися на свинофермах ЕС та свідчать про відсутність ДНК P. acanthamoebae у зразках відібраних від свиней або досить низьку преваленцію (Koschwanez et al., 2012; Van Gils et al., 2015). Стосовно W. chondrophila - то ДНК $W$. chondrophila у зразках від свиней було виявлено вперше у світі. В доступних для нас літературних джерелах даних про виявлення W. chondrophila у свиней немає.

Це може бути пов'язано зі значними відмінностями в організації ферм та відмінностями ведення господарства у свинарстві ЕС та Україні, природнокліматичними відмінностями, географічним походженням, різними екологічними умовами, вибіркою досліджуваних свиней, різними умовами годівлі та різними методами діагностики. Система вирощування свиней в окремих господарствах України не досконала й існує порівняно більше шансів вступити в контакт з гризунами, птахами та іншими тваринами, що є джерелом хламідійної інфекції (Herasymov, 2010).

\section{Висновки}

В результаті проведених досліджень вперше було виявлено хламідієподібний організм $W$. chondrophila у свиней. Ідентичність ПЛР продукту була доведена рестрикційним аналізом. Серед тварин з репродукти- вними розладами 28,7\% були $W$. chondrophila позитивними, і лише 7,14\% серед вищезазначеної кількості тварин виявилися Chlamydiaceae-позитивними. Такий незначний відсоток Chlamydiaceae-позитивних тварин обумовлений профілактичними заходами, щодо хламідійної інфекції, що проводилися в господарствах: дослідження ПЛР-тест системами, націленими на виявлення бактерій родини Chlamydiaceae, після чого Chlamydiaceae- позитивні тварини піддавалися лікування або вибраковувалися. Коінфекція Chlamydiaceae та W. chondrophila були виявлені в одному випадку, що свідчить про гіпотетичну можливість рекомбінації генів бактерій родин Chlamydiaceae та Waddliaceae, що може поліпшити адаптивні властивості вищезгаданих бактерій. Незважаючи на вищезазначене, незначна кількість зразків як у нашому, так і в попередніх дослідженнях не дає можливості зробити висновки, щодо преваленції хламідієподібних організмів у свиней. Необхідні подальші дослідження, які допомогли б пролити світло на те, наскільки значущою є ця знахідка і яку роль $W$. chondrophila відіграє для свинарства.

Перспективи подальших досліджень. Подальші дослідження включатимуть ширшу вибірку тварин, виділення збудника, секвенування його геному з подальшим його аналізом, проведення експериментальних заражень тварин з визначенням патоморфологічних змін.

Подяки. Щиро дякую вченим, які відгукнулися: Dr. Michel Rolf, Gilbert Greub, Dr. Christiane Schnee, Heike Schmidt-Posthaus - за ту неоціненну допомогу, яку ви нам надали у вигляді зразків контрольних ДНК, завдяки чому стало можливим виконання поставлених перед нами завдань.

Також хочу висловити свою найщирішу вдячність тим, без котрих дані дослідження були б неможливими: Ксьонзу Ігору Миколайовичу, Почерняєву Костянтину Федоровичу, Буслик Тетяні Володимирівні, Передері Сергію Борисовичу, які, не шкодували сил і часу, надихали і завжди спрямовували свій талант на досягнення успіху в нашій спільній справі.

\section{References}

Baud, D., Goy, G., Osterheld, M.-C., Croxatto, A., Borel, N., Vial, Y., ... Greub, G. (2014). Role of Waddlia chondrophila Placental Infection in Miscarriage. Emerging Infectious Diseases, 20(3), 460-464. doi: 10.3201/eid2003.131019.

Borel, N., Polkinghorne, A., \& Pospischil, A. (2018). A Review on Chlamydial Diseases in Animals: Still a Challenge for Pathologists? Veterinary Pathology, 55(3), 374-390. doi: 10.1177/0300985817751218.

Burnard, D., \& Polkinghorne, A. (2016). Chlamydial infections in wildlife-conservation threats and/or reservoirs of 'spill-over' infections? Veterinary Microbiology, 196, 78-84. doi: 10.1016/j.vetmic. 2016.10.018.

Di Francesco, A., Baldelli, R., Donati, M., Cotti, C., Bassi, P., \& Delogu, M. (2013). Evidence for 
Chlamydiaceae and Parachlamydiaceae in a wild boar (Sus scrofa) population in Italy. Veterinaria Italiana, 49(1), 119-122. https://www.ncbi.nlm.nih.gov/ pubmed/23564593.

Greub, G. (2009). Parachlamydia acanthamoebae, an emerging agent of pneumonia. Clinical Microbiology and Infection: The Official Publication of the European Society of Clinical Microbiology and Infectious Diseases, 15(1), 18-28. doi: 10.1111/j.1469-0691.2008.02633.x.

Herasymov, V.I. (2010). Tekhnolohiia vyrobnytstva produktsii svynarstva. Kharkiv: Espada (in Ukrainian).

Hoffmann, K., Schott, F., Donati, M., Di Francesco, A., Hässig, M., Wanninger, S., ... Borel, N. (2015). Prevalence of Chlamydial Infections in Fattening Pigs and Their Influencing Factors. PLOS ONE, 10(11), e0143576. doi: 10.1371/journal.pone.0143576.

Hornung, S., Thuong, B. C., Gyger, J., Kebbi-Beghdadi, C., Vasilevsky, S., Greub, G., \& Baud, D. (2015). Role of Chlamydia trachomatis and emerging Chlamydia-related bacteria in ectopic pregnancy in Vietnam. Epidemiology \& Infection, 143(12), 26352638. doi: 10.1017/S0950268814003616.

Joseph, S. J., Marti, H., Didelot, X., Read, T. D., \& Dean, D. (2016). Tetracycline Selective Pressure and Homologous Recombination Shape the Evolution of Chlamydia suis: A Recently Identified Zoonotic Pathogen. Genome Biology and Evolution, 8(8), 2613-2623. doi: 10.1093/gbe/evw182.

Kohlhoff, S.A., \& Hammerschlag, M.R. (2015). Treatment of chlamydial infections: 2014 update. Expert Opinion on Pharmacotherapy, 16(2), 205-212. doi: 10.1517/14656566.2015.999041.

Kong, F.Y.S., Tabrizi, S.N., Fairley, C.K., Vodstrcil, L.A., Huston, W.M., Chen, M., ... Hocking, J.S. (2015). The efficacy of azithromycin and doxycycline for the treatment of rectal chlamydia infection: A systematic review and meta-analysis. Journal of Antimicrobial Chemotherapy, 70(5), 1290-1297. doi: $10.1093 / \mathrm{jac} / \mathrm{dku} 574$.

Koschwanez, M., Meli, M., Vögtlin, A., Greub, G., Sidler, X., Handke, M., ... Borel, N. (2012). Chlamydiaceae family, Parachlamydia spp., and Waddlia spp. In porcine abortion. Journal of Veterinary Diagnostic Investigation: Official Publication of the American Association of Veterinary Laboratory Diagnosticians, Inc, 24(5), 833-839. doi: $10.1177 / 1040638712452729$.

Ksonz, I.M., \& Pocherniaiev, K.F. (2009). Sposib vyznachennia dnk bakterii rodyny chlamydiaceae $u$ polimeraznii lantsiuhovii reaktsii shliakhom amplifikatsii frahmenta hena holovnoho bilka membrany (momr)-UA 51635. Retrieved from http:/uapatents.com/2-51635-sposib-viznachennyadnk-bakterijj-rodini-chlamydiaceae-u-polimeraznijjlancyugovijj-reakci-shlyakhom-amplifikacifragmenta-gena-golovnogo-bilka-membranimomr.html (in Ukrainian).

Ksonz, I.M. (2014). Epizootychnyi stan shchodo khlamidiinoi infektsii u pleminnomu svynarstvi. Tvarynnytstvo Veterynarna Medytsyna, (10), 34-36 (in Ukrainian).

Longbottom, D. (2004). Chlamydial infections of domestic ruminants and swine: New nomenclature and new knowledge. The Veterinary Journal, 168(1), 911. doi: 10.1016/S1090-0233(03)00106-0.

Schautteet, K., \& Vanrompay, D. (2011). Chlamydiaceae infections in pig. Veterinary Research, 42(1), 29. doi: 10.1186/1297-9716-42-29.

Stephan, S., Guerra, D., Pospischil, A., Hilbe, M., Weissenböck, H., Novotný, L., ... Borel, N. (2014). Chlamydiaceae and chlamydia-like organisms in freeliving small mammals in europe and afghanistan. Journal of Wildlife Diseases, 50(2), 195. doi: 10.7589/2013-08-194.

Suchland, R.J., Sandoz, K.M., Jeffrey, B.M., Stamm, W.E., \& Rockey, D.D. (2009). Horizontal Transfer of Tetracycline Resistance among Chlamydia spp. In Vitro. Antimicrobial Agents and Chemotherapy, 53(11), 4604-4611. doi: 10.1128/AAC.00477-09.

Taylor-Brown, A., \& Polkinghorne, A. (2017). New and emerging chlamydial infections of creatures great and small. New Microbes and New Infections, 18, 28-33. doi: 10.1016/j.nmni.2017.04.004.

Van Gils, M., Aeby, S., Vanrompay, D., \& Greub, G. (2015). Absence of Chlamydia-like organisms in pigs. New Microbes and New Infections, 7, 31-32. doi: 10.1016/j.nmni.2015.04.007.

Zezekalo, V.K., Pedera, S.B., Buslik, T.V., \& Pochernyaev, K.F. (2019). PCR-test for identification and species differentiation of Waddlia chondrophila. Scientific Messenger of LNU of Veterinary Medicine and Biotechnology, 21(93), 143-148. doi: 10.32718/nvlvet9325 (in Ukrainian).

Zezekalo, V.K., Pepedera, S.B., \& Shcherbakova, N.S. (2019). Uzahalnennia informatsii shchodo khlamidiinykh infektsii tvaryn ta yikh zoonoznoho potentsialu. Visnyk Poltavskoi Derzhavnoi Ahrarnoi Akademii, (2), 171-182. doi: 10.31210/visnyk2019. 02.23 (in Ukrainian).

Zezekalo, V.K., Peredera, S.B., Buslik, T.V., \& Pochernyaev, K.F. (2018). PCR-test system specific identification Parachlamydia acanthamoebae. Scientific Messenger of LNU of Veterinary Medicine and Biotechnologies, 20(92), 101-104. doi: 10.32718/nvlvet9220 (in Ukrainian). 